\title{
PENGARUH TEMPORARY DIFFERENCE DAN PERMANENT DIFFERENCE TERHADAP PERTUMBUHAN LABA DENGAN UKURAN PERUSAHAAN SEBAGAI VARIABEL PEMODERASI
}

(Studi Empiris Pada Perusahaan Manufaktur Yang Terdaftar di BEI)

\author{
Abdullah Mubarok \\ Dosen Universitas Pamulang
}

\begin{abstract}
The sample of this research used manufacture industry which listed in Indonesia Stock Exchange during 2013-2016 period. The number of manufacture industries were consisted of 14 companies with 4 years observation. This research based on purposive sampling method. The total of research samples are 56 financial statements. Hypothesis in this research are tested by multiple regression analysis and MRA (Moderated Regression Analysis). The results of this study show that the significant value of temporary differences is 0.000 , and permanent differencehas a significant value of 0.015 , the results show significant value less than 0.050, it can be concluded that temporary difference and permanent difference significantly influence earning changes, and firm size has a significant value of 0.548 , the results show significant value great off 0.050 , it can be concluded that firm size can't significantly influence earning changes. This study found evidence of the interaction between temporary difference and firm size that showed significant value of 0.026 less than 0.050 , from the result it can be concluded that the interaction between temporary difference and firm size significantly influence earning changes. And This study found evidence of the interaction between permanent difference and firm size that showed significant value of 0.023 less than 0.050, from the result it can be concluded that the interaction between permanent difference and firm size significantlyinfluence earning changes

Keyword: Temporary Differences, Permanent Differences, Earning Changes, Firm Size.
\end{abstract}

\begin{abstract}
Abstrak: Penelitian ini menggunakan sampel perusahaan manufaktur yang terdaftar di Bursa Efek Indonesia selama periode 2013-2016. Jumlah perusahaan manufaktur yang dijadikan sampel penelitian adalah 14 perusahaan dengan pengamatan selama 4 tahun. Penelitian ini berdasarkan purposive sampling. Total sampel penelitian ini adalah 56 laporan keuangan. Pengujian hipotesis dalam penelitian ini menggunakan teknik analisis regresi berganda dan MRA (Moderated Regression Analysis).Hasil penelitian ini menunjukan bahwa nilai signifikan temporary differences sebesar 0.000 , permanent differences sebesar 0,015 dan ukuran perusahaanmemilikinilai signifikansebesar 0,548 , dari hasil tersebut menunjukkan nilai signifikan lebih kecil dari 0.050 , maka dapat disimpulkan bahwa temporary difference dan permanent difference berpengaruh secara signifikan terhadap pertumbuhan laba, dan ukuran perusahaan memiliki nilai signifikan sebesar 0,548, yangmenunjukkan nilai signifikan lebih besar dari 0.050, maka ukuran perusahaan tidak berpengaruh terhadap pertumbuhan laba. Penelitian ini menemukan bukti mengenai interaksi antara temporary difference dengan ukuran perusahaan yang menunjukkan nilai signifikan sebesar 0,026 dan permanent differencedengan ukuran perusahaan yang menunjukkan nilai signifikan sebesar 0,023 lebih kecil dari 0.050, dari hasil tersebut dapat disimpulkan bahwa interaksi antara temporary differencedengan ukuran perusahaan berpengaruh secara signifikan terhadap pertumbuhan laba.Dan permanent differencedengan ukuran perusahaan berpengaruh secara signifikan terhadap pertumbuhan laba.
\end{abstract}

Kata kunci: Temporary Difference, Permanent Difference,Pertumbuhan Laba, Ukuran Perusahaan. 


\section{Pendahuluan}

Adanya dasar penyusunan yang berbeda dalam penghitungan laba menurut komersial dengan menurut perpajakan maka menyebabkan perbedaan jumlah antara penghasilan sebelum pajak (laba akuntansi) dengan penghasilan kena pajak (laba fiskal) atau yang dapat disebut dengan Book Tax Differences. Penyebab perbedaan yang terjadi antara penghasilan sebelum pajak dengan penghasilan kena pajak dapat dikategorikan menjadi perbedaan permanen (permanent differences) dan perbedaan temporer (temporaty differences) atau perbedaan waktu (timing differences). Perbedaan permanen timbul karena adanya perbedaan tujuan dan fungsinya serta rugi yang diderita pada tahuntahun sebelumnya yang dapat dikompensasikan atas laba tahun berjalan (loss carryforward) Hutagol(2006:77) dalam Suhendar (2015:4) serta peraturan yang berbeda terkait dengan pengakuan penghasilan dan biaya antara Standar Akuntansi Keuangan dengan Ketentuan Peraturan Perundangundangan Perpajakan. Dengan demikian, manajemen berkewajiban melakukan penyesuaian atas laba akuntansinyadengan ketentuan perpajakan yang berlaku untuk menghitung laba fiskal atau biasa disebut dengan rekonsiliasi fiskal. Perbedaan temporer (temporaty difference) yang timbul, tercermin dalam laporan keuangan komersial sebagai pajak tangguhan (deferred taxes). Pajak tangguhan dapat berupa aset pajak tangguhan dan kewajiban pajak tangguhan.

Penelitian tersebut memberi bukti bahwa adanya Book Tax Differences menjadi indikasi terjadinya praktik manajemen laba yang dilakukan oleh perusahaan (Mills dan Newberry, (2001) Phillips et al., (2003) Tang, (2006) Ayers et al. (2008) dalam Budi Lestari (2011). Selain itu beberapa penelitian menyatakan bahwa booktax differencejuga dapat digunakan untuk mengetahui kualitas laba terutama dalam kaitannya dengan persistensi laba Hanlon, (2005) Wiryandari dan Yulianti, (2008) dalam Budi Lestari (2011:3).

Dari penelitian-penelitian sebelumnya dapat disimpulkan bahwa Book Tax Differences berkaitan dengan informasi laba sehingga dapat digunakan untuk mengevaluasi kinerja perusahaan. Namun, manfaat Book Tax Differences tersebut tidak selalu timbul akibat adanya praktik manajemen laba yang dilakukan perusahaan. Book Tax Differences juga timbul akibat adanya perbedaan aplikasi antara ketentuan akuntansi berdasarkan Standar Akuntansi Keuangan dengan ketentuan fiskal berdasarkan Undang-Undang perpajakan dan tidak disebabkan oleh adanya unsur oportunistik pihak manajemen seperti melakukan manajemen laba (earnings management) dan perencanaan pajak (tax planning). Perbedaan ini menyebabkan transaksi yang sama dapat diperlakukan secara berbeda oleh perusahaan. Ukuran perusahaan menggambarkan besar kecilnya suatu perusahaan yang ditunjukan oleh total aktiva ( Sigit dalam Hana Tiara (2012:2).

Berdasarkan uraian di atas maka perumusan yang muncul dalam penelitian ini adalah : 1) Apakah temporary difference dari Book Tax Differences berpengaruh terhadap pertumbuhan laba?, 2) Apakah permanent difference dari Book Tax Differences berpengaruh terhadap pertumbuhan laba?, 3) Apakahtemporary differencedengan ukuran perusahaan berpengaruh terhadap pertumbuhan laba?, dan 4) Apakah permanent difference dengan ukuran perusahaan berpengaruh dengan pertumbuhan laba?

\section{Landasan Teori}

\subsection{Pengertian Laba}

Pengertian laba secara operasional merupakan perbedaan antara pendapatan yang direalisasi yang timbul dari transaksi selama satu periode dengan biaya yang berkaitan dengan pendapatan tersebut. Pengertian laba menurut Harahap (2011:300) "kelebihan penghasilan di atas biaya selama satu periode akuntansi". Sementara pengertian laba yang dianut oleh struktur akuntansi sekarang ini adalah selisih pengukuran pendapatan dan biaya (Chariri dan Ghozali, 2003 dalam Anik Fadilah, 2013:20). Besar kecilnya laba sebagai pengukur kenaikan sangat bergantung pada ketepatan pengukuran pendapatan dan biaya. Maka dari itu, laba bersih suatu perusahaan yang disajikan dalam 
laporan keuangan diperoleh setelah semua pendapatan atau penghasilan diakumulasi lalu dikurangi dengan akumulasi beban atau biaya yang dikorbankan perusahaan (termasuk pajak penghasilan) dalam rangka mendapatkan atau memperoleh laba pada suatu periode.

\subsubsection{Perbedaan Temporer (Temporary Differences)}

Perbedaan temporer (temporary difference) disebabkan karena adanya perbedaan waktu pengakuan penghasilan dan biaya untuk penghitungan laba. Perbedaan ini terjadi karena berdasarkan ketentuan peraturan perundang-undangan perpajakan terdapat penghasilan atau biaya yang boleh dikurangkan pada periode akuntansi terdahulu atau periode akuntansi berikutnya dari periode akuntansi sekarang. Sementara itu, komersial mengakuinya sebagai penghasilan atau biaya pada periode yang bersangkutan. (Zain 2008:213). Cara menghitung temporary difference adalah dengan cara menjumlah semua pos-pos perbedaan temporer dibagi dengan total aset. Temporary difference dalam penelitian ini diukur dengan membagi minus beban pajak tangguhan dengan tarif pajak yang berlaku $(\mathrm{t})$ dikalikan dengan perbandingan 1 dikurangi tarif pajak kini $(\mathrm{t})$ yang dibagi oleh aktiva rata-rata menurut Jackson (2011) dalam Saputro (2011) sebagai berikut:

$$
\text { Perbedaan Temporer }=\frac{\text {-Beban pajak tangguhan }}{\mathrm{t}} \times \frac{(1-\mathrm{t})}{\text { aktiva rata }- \text { rata }}
$$

\subsubsection{Perbedaan Permanen (Permanent Differences)}

Perbedaan permanen (permanent difference) disebabkan oleh pengaturan yang berbeda terkait dengan pengakuan penghasilan dan biaya antara Standar Akuntansi Keuangan dengan Ketentuan Peraturan Perundang-undangan Perpajakan. Jadi dapat dikatakan bahwa berdasarkan ketentuan peraturan perundang-undangan perpajakan, ada beberapa penghasilan yang bukan merupakan objek pajak, sedangkan secara komersial penghasilan tersebut diakui sebagai penghasilan. Begitu juga sebaliknya, ada beberapa biaya sesuai ketentuan perundang-undangan perpajakan termasuk biaya fiskal yang tidak boleh dikurangkan, sedangkan Penghasilan Sebelum Pajak (Pretax Income) Penghasilan Kena Pajak (Taxable Income) menurut komersial biaya tersebut diperhitungkan sebagai biaya. Pada umumnya perbedaan permanen yang terjadi akibat perbedaan pengakuan penghasilan dan biaya. Cara menghitung permanent difference adalah dengan cara menjumlah semua pos-pos perbedaan permanen dibagi dengan total aset. Permanent difference (PERM) dalam penelitian ini diukur dengan mengurangkan temporary difference (TEMP) terhadap Book Tax Difference (BTD) menurut Jackson (2011) dalam Fadilah (2013:52) adalah sebagai berikut:

\section{PERM $=$ BTD - TEMP}

\subsubsection{Pertumbuhan Laba}

Ghozali dan Chariri (2003 :349) mengemukakan bahwa salah satu tujuan pelaporan keuangan adalah memberikan informasi keuangan yang dapat menunjukkan prestasi perusahaan dalam menghasilkan laba (earning per share). Laba adalah hasil dari suatu periode yang telah dicapai oleh perusahaan sebagaimana disebutkan dalam Statement of Financial Accounting Standards(SFAS) nomor 1, laba merupakan salah satu informasi potensial yang terkandung di dalam laporan keuangan dan yang sangat penting bagi pihak internal maupun eksternal perusahaan, untuk melakukan penaksiran earning power perusahaan dimasa yang akan datang. Belkaoui (1993) menyatakan bahwa laba merupakan suatu pos dasar dan penting dari ikhtisar keuangan yang memiliki berbagai kegunaan 
dalam berbagai konteks. Laba umumnya dipandang sebagai suatu dasar bagi perpajakan,determinan pada kebijakan pembayaran dividen, pedoman investasi, pengambilan keputusan dan unsur prediksi.

\subsubsection{Ukuran Perusahaan}

Ukuran perusahaan merupakan suatu variabel untuk mengukur seberapa besar atau kecil perusahaan yang dijadikan sampel. Besar ukuran perusahaan dapat dinyatakan dalam total aktiva, penjualan, dan kapitalisasi pasar. Semakin besar total aktiva, penjualan, dan kapitalisasi pasar maka semakin besar pula ukuran suatu perusahaan. Dari ketiga variabel ini, nilai aktiva relatif lebih stabil dibandingkan dengan market capitalized dan penjualan dalam mengukur ukuran perusahaan (Sudarmadji dan Sularto, 2007). Ukuran perusahaan yang tercermin pada kinerja perusahaan merupakan salah satu ukuran untuk menilai perusahaan. Besar kecilnya suatu perusahaan biasanya diukur berdasarkan total penjualan, rata-rata tingkat penjualan dan total aktiva (Panjaitan dkk, 2004 dalam Alfiarini 2015:32).

\subsection{Kerangka Berpikir}

Terdapat dugaan bahwa keadaan awal perusahaan yang mempunyai Ukuran Perusahaan memiliki pertumbuhan laba yang baik, jika hal ini dipadukan dengan permanent difference yang diduga juga berhubungan positif dengan pertumbuhan laba, maka besar pengaruh positif itu akan bertambah dan akan banyak mempengaruhi pertumbuhan pertumbuhan laba perusahaan karena memang pada dasarnya laba perusahaan sudah terdukung tinggi dengan adanya Ukuran Perusahaan. Sehingga akan menimbulkan pengaruh positif antara variabel bebas terhadap variabel terikat. Maka dapat diambil kerangka pemikian sebagai berikut:

\section{Gambar 2.1. Kerangka Pikir}

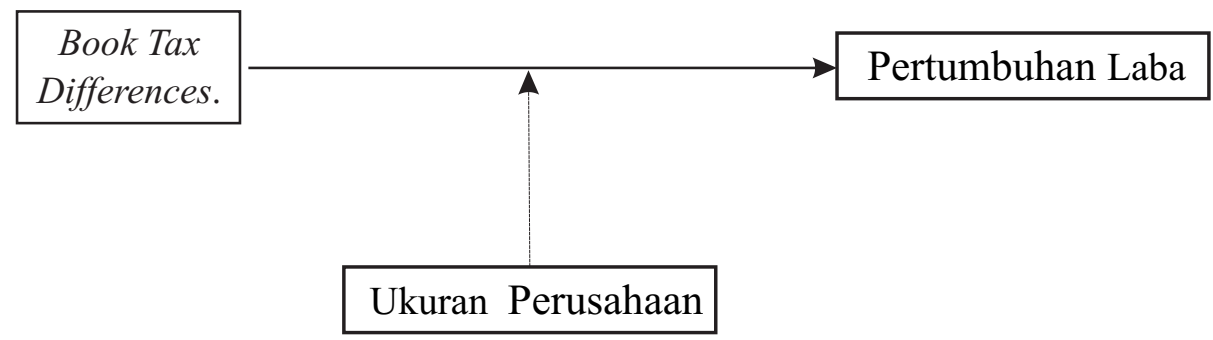

Sumber: Olah data penulis 2017

\subsection{Hipotesis}

Variabel Penelitian ini terdiri dari variabel terikat pertumbuhan laba. Variabel bebas yaitu temporary difference, permanent difference dan total book-tax differences. Variabel moderating ukuran perusahaan Berdasarkan landasan teori, hubungan antar variabel dan hasil penelitian sebelumnya, maka kerangka pemikiran dalam penelitian ini adalah sebagai berikut :

$\mathrm{X}_{1}=$ Variabel Independen Temporary Difference

$\mathrm{X}_{2}=$ Variabel Independen Permanent Difference

$\mathrm{Z}=$ Variabel Pemoderasi Ukuran Perusahaan

$\mathrm{Y}=$ Variable Dependen Pertumbuhan Laba

Hipotesis adalah pernyataan tentang sesuatu yang untuk sementarawaktu dianggap benar. Selain itu juga, hipotesis dapat diartikan sebagai pernyataan yang akan diteliti sebagai jawaban sementara dari suatu masalah.Berdasarkan rumusan masalah, tujuan teori, penelitian terdahulu, hubungan antara variable dan kerangka pemikiran maka hipotesis yang akan diajukan dalam penelitian ini adalah sebagai berikut : 
H1 : Temporary Difference berpengaruh terhadap pertumbuhan laba perusahaan satu periode kedepan.

H2 : Permanent difference berpengaruh terhadap pertumbuhan laba perusahaan satu periode kedepan.

H3 : Pengaruh temporary difference dengan ukuran perusahaan dan pengaruhnya terhadap pertumbuhan laba perusahaan satu periode kedepan

H4 : Pengaruh permanet difference dengan ukuran perusahaan dan pengaruhnya terhadap pertumbuhan laba perusahaan satu periode kedepan

\section{Metodologi Penelitian}

\subsection{Metode Penentuan Sampel}

Sampel adalah sebagian/wakil populasi yang akan diteliti (Arikunto, 2002). Sampel yang dipilih dari populasi dianggap mewakili keberadaan populasi. Populasi adalah keseluruhan gejala atau satuan yang ingin diteliti (Bambang dan Lina, 2006: 119). Populasi penelitian ini adalah perusahaan manufaktur yang terdaftar di BEI pada tahun 2013-2016. Adapun metode pemilihan sampel penelitian menggunakan purposive sampling. Purposive sampling merupakan suatu metode pengambilan sampel non probabilita yang disesuaikan dengan kriteria tertentu.

\subsection{Metode Pengumpulan Data}

Metode pengumpulan data menggunakan penelusuran data sekunder melalui metode dokumentasi. Dokumentasi dilakukan dengan mengumpulkan sumber- sumber data dokumenter seperti laporan tahunan dan melihat summary of financial statment pada ICaMEL ( Indonesia Capital Market Electronic Library) perusahaan yang menjadi penelitian.

\subsection{Operasional Variabel Penelitian}

Variabel yang digunakan dalam penelitian ini adalah variabel independen,variabel moderating dan variabel dependen. Variabel independen dalam penelitian ini adalah perbedaan permanen dan perbedaan temporer, dan variabel moderating adalah ukuran perusahaan sedangkan variabel dependen yaitu pertumbuhan laba.

Tabel 3.1

Pengukuran Variabel

\begin{tabular}{|l|l|l|l|}
\hline \multicolumn{1}{|c|}{$\begin{array}{c}\text { Jenis } \\
\text { Variabel }\end{array}$} & $\begin{array}{c}\text { Variabel Yang } \\
\text { Diteliti }\end{array}$ & \multicolumn{1}{|c|}{ Teori Peneliti } & Skala \\
\hline Independen & $\begin{array}{l}\text { Permanent } \\
\text { Differences }\end{array}$ & $\frac{\text { Permanent Differences }}{\text { Total Aktiva }}$ & Rasio \\
\hline Independen & $\begin{array}{l}\text { Temporary } \\
\text { Difference }\end{array}$ & $\frac{\text { Temporary Differences }}{\text { Total Aktiva }}$ & Rasio \\
\hline Moderating & $\begin{array}{l}\text { Ukuran } \\
\text { Perusahaan }\end{array}$ & $\begin{array}{l}\text { Logaritma Natural dari Total Aset } \\
\text { TAit }=\text { Total Aktiva Perusahaan i } \\
\text { pada tahun t }\end{array}$ & Rasio \\
\hline Dependen & $\begin{array}{l}\text { Pertumbuhan } \\
\text { Laba }\end{array}$ & $\begin{array}{l}\text { Persistensi laba diukur } \\
\text { menggunakan koefisien regresi }(\gamma 1) \\
\text { antara laba akuntansi sebelum pajak } \\
\text { pada satu perioda masa depan } \\
\text { (PTBI t+1) dengan laba akuntansi } \\
\text { sebelum pajak perioda sekarang } \\
\text { dengan menambahan ukuran } \\
\text { perusahaan sebagai pemoderasi }\end{array}$ & Rasio \\
\hline
\end{tabular}

Sumber : Olah data penulis 2017 


\subsection{Metode Analisis}

Adapun metode analisi data yang digunakan adalah Uji Asumsi Klasik, Uji Regresi Linear Berganda, Koefisien Determinasi ( R2), Uji Signifikansi Simultan (Uji Statistik F), Uji Signifikansi Parameter Individual (Uji Statistik t), dan Moderate Regression Analysis (MRA).

\section{Hasil Penelitian Dan Pembahasan}

\subsection{Analisis Statistik Deskriptif}

Berikut adalah pengujian variabel-variabel tersebut secara statistik deskriptif menggunakan SPSS 22

Tabel 4.1

Hasil Uji Statistik Deskriptif

Descriptive Statistics

\begin{tabular}{|l|r|r|r|r|r|}
\hline & $\mathrm{N}$ & \multicolumn{1}{|c|}{ Minimum } & Maximum & \multicolumn{1}{c|}{ Mean } & \multicolumn{1}{c|}{ Std. Deviation } \\
\hline Temporary & 56 &,- 14 &, 02 &,- 0021 &, 02106 \\
Permanent & 56 &,- 03 &, 01 &,- 0020 &, 00906 \\
Size & 56 & 26,27 & 31,42 & 28,3711 & 1,60676 \\
Pertumbuhan Laba & 56 &,- 78 & 2,24 &, 0311 &, 42837 \\
Valid N (listwise) & 56 & & & & \\
\hline
\end{tabular}

Sumber : Hasil pengolahan data menggunakan SPSS 22, 2017

\subsection{Uji Asumsi Klasik}

\subsubsection{Uji Normalitas}

Uji normalitas residual digunakan untuk menentukan apakah data terdistribusi normal atau tidak pengujian normalitas residual dalam penelitian ini menggunakan uji kolmogorov-smirnov. Hasil pengujian normalitas residual sebelum uji outlier dapat dilihat pada tabel 4.2 berikut ini:

Tabel 4.2

Hasil Uji Kolmogrov-Smirnov (K-S)

One-Sample Kolmogorov-Smirnov Test

\begin{tabular}{|ll|r|}
\hline & & \\
\hline $\mathrm{N}$ & & Unstandardized Residual \\
\hline Normal Parameters & & 56 \\
& Mean &, 0000000 \\
Most Extreme Differences & Std. Deviation &, 30174069 \\
& Absolute &, 085 \\
& Positive &, 085 \\
Test Statistic & Negative &,- 071 \\
Asymp. Sig. (2-tailed) & &, 085 \\
\hline
\end{tabular}
a. Test distribution is Normal.
b. Calculated from data.
c. Lilliefors Significance Correction.
d. This is a lower bound of the true significance.

Sumber : Hasil pengolahan data menggunakan SPSS 22, 2017.

Selain uji Kolmogorov-Smirnov, uji normalitas juga dilakukan dengan menggunakan normal probability plot. Hasil uji normalitas menggunakan normal probability plot pada gambar 4.1 adalah sebagai berikut: 
Gambar 4.1.

\section{Normal probability plot}

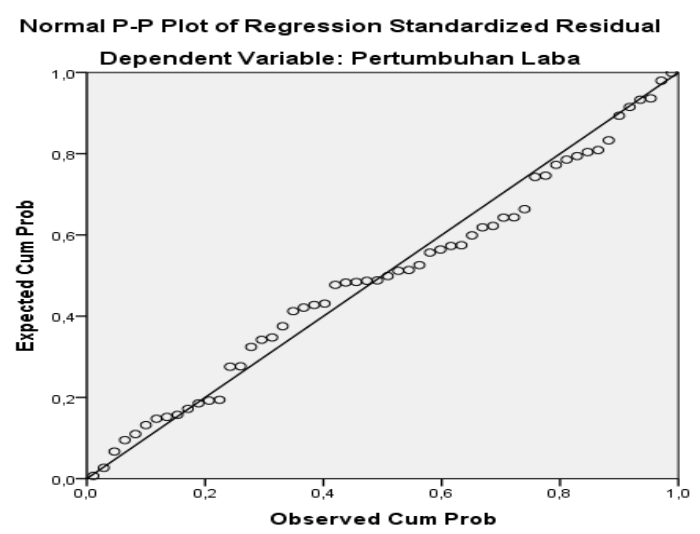

Sumber : Hasil pengolahan data menggunakan SPSS 22, 2017

\subsubsection{Uji Multikolinearitas}

Hasil pengujian multikolinearitas dapat dilihat pada tabel 4.3. berikut ini:

Tabel 4.3. Uji Multikolinearitas

\begin{tabular}{|c|c|c|c|c|c|c|c|c|}
\hline \multicolumn{9}{|c|}{ Coefficients $^{a}$} \\
\hline \multirow{2}{*}{\multicolumn{2}{|c|}{ Model }} & \multicolumn{2}{|c|}{$\begin{array}{l}\text { Unstandardized } \\
\text { Coefficients }\end{array}$} & \multirow{2}{*}{$\begin{array}{c}\text { Standardized } \\
\text { Coefficients } \\
\text { Beta }\end{array}$} & \multirow[b]{2}{*}{$t$} & \multirow[b]{2}{*}{ Sig. } & \multicolumn{2}{|c|}{ Collinearity Statistics } \\
\hline & & $\mathrm{B}$ & Std. Error & & & & Tolerance & VIF \\
\hline & (Constant) & 477 &, 745 & & 640 &, 525 & & \\
\hline & Temporary & $-12,638$ & 2,019 &,- 621 & $-6,260$ & ,000 & 968 & 1,033 \\
\hline & Permanent & 11,759 & 4,679 & ,249 & 2,513 & ,015 & ,975 & 1,025 \\
\hline & Size &,- 016 & ,026 &,- 059 &,- 604 &, 548 & 990 & 1,010 \\
\hline
\end{tabular}

a. Dependent Variable: Pertumbuhan Laba

Sumber : Hasil pengolahan data menggunakan SPSS 22, 2017

Berdasarkan hasil iji multikolionearitas pada tabel 4.3, dapat disimpulkan bahwa model regresi yang ada tidak terdapat multikolionearitas karena variabel temporary difference, permanent difference dan Ukuran perussahaan mempunyai nilai tolerance di atas 0,1 dan nilai Variance Inflation Factor $(V I F)$ kurang dari 10 . Hal ini berarti tidak terjadi multikolionearitas antar variabel terikat.

\subsubsection{Uji Heteroskedastisitas}

Hasil pengujian Heteroskedastisitas dapat dilihat pada gambar 4.2 berikut ini:

Gambar 4.2. Uji Heteroskedastisitas Scatterplot

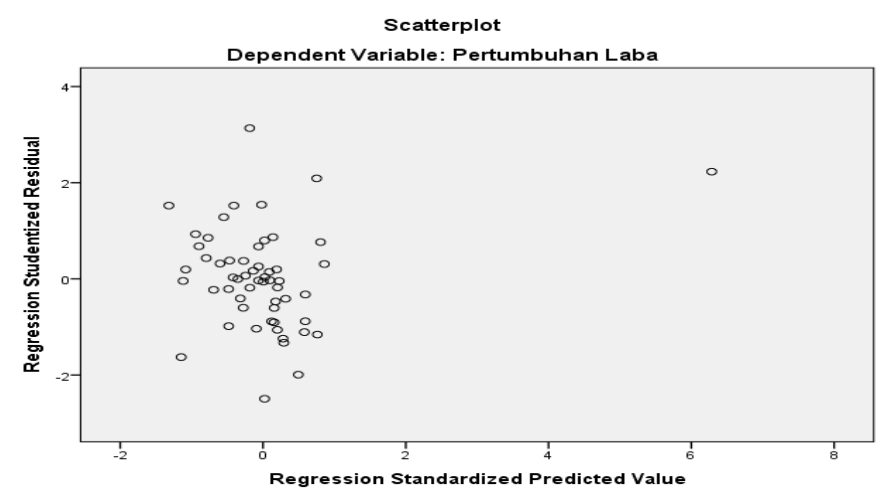

Sumber : Hasil pengolahan data menggunakan SPSS 22, 2017 


\subsubsection{Uji Regresi Berganda}

Analisis regresi adalah analisis untuk mengetahui seberapa besar suatu variabel berpengaruh pada variabel lainnya. Dalam hal ini kita akan melihat berapa besar pengaruh perubahan variabel bebas terhadap variabel terikat.

Tabel 4.4

Hasil Uji Linear Berganda

Coefficients $^{a}$

\begin{tabular}{|c|c|c|c|c|c|c|c|c|}
\hline \multirow{2}{*}{\multicolumn{2}{|c|}{ Model }} & \multicolumn{2}{|c|}{$\begin{array}{l}\text { Unstandardized } \\
\text { Coefficients }\end{array}$} & \multirow{2}{*}{$\begin{array}{c}\text { Standardized } \\
\text { Coefficients } \\
\text { Beta }\end{array}$} & \multirow[b]{2}{*}{$t$} & \multirow[b]{2}{*}{ Sig. } & \multicolumn{2}{|c|}{$\begin{array}{l}\text { Collinearity } \\
\text { Statistics }\end{array}$} \\
\hline & & $\mathrm{B}$ & Std. Error & & & & Tolerance & VIF \\
\hline \multirow[t]{4}{*}{1} & (Constant) & ,477 & ,745 & & ,640 & ,525 & & \\
\hline & Temporary & $-12,638$ & 2,019 &,- 621 & $-6,260$ & ,000 & ,968 & 1,033 \\
\hline & Permanent & 11,759 & 4,679 & ,249 & 2,513 & ,015 & ,975 & 1,025 \\
\hline & Size &,- 016 & ,026 &,- 059 &,- 604 & ,548 & ,990 & 1,010 \\
\hline
\end{tabular}

a. Dependent Variable: Pertumbuhan Laba

Sumber : Hasil pengolahan data menggunakan SPSS 22, 2017

Berdasarkan tabel tersebut maka persamaan regresi yang digunakan dalam penelitian ini adalah sebagai berikut:

$\mathrm{Y}=-12,638+11,759-0,016 \mathrm{X}_{2}+\mathrm{e}$

\subsubsection{Uji Koefisien Determinasi (Adjusted R-Square)}

Hasil pengujian Koefisien Determinasi (Adjusted R-Square) dapat dilihat dari tabel 4.5 berikut ini :

Tabel 4.5.

Hasil Uji Koefisien Determinasi

Model Summary ${ }^{\mathrm{b}}$

\begin{tabular}{|l|r|r|r|r|}
\hline Model & $\mathrm{R}$ & R Square & Adjusted R Square & $\begin{array}{c}\text { Std. Error of the } \\
\text { Estimate }\end{array}$ \\
\hline 1 &, $710^{\mathrm{a}}$ &, 504 &, 475 &, 31032 \\
\hline
\end{tabular}

a. Predictors: (Constant), Size, Permanent, Temporary

b. Dependent Variable: Pertumbuhan Laba

Sumber : Hasil pengolahan data menggunakan SPSS 22, 2017

\subsubsection{Uji Hipotesis}

\section{Ujit}

Tabel 4.6

Uji t

\begin{tabular}{|c|c|c|c|c|c|c|}
\hline \multirow{2}{*}{\multicolumn{2}{|c|}{ Model }} & \multicolumn{2}{|c|}{$\begin{array}{l}\text { Unstandardized } \\
\text { Coefficients }\end{array}$} & \multirow{2}{*}{$\begin{array}{c}\text { Standardized } \\
\text { Coefficients } \\
\text { Beta } \\
\end{array}$} & \multirow[b]{2}{*}{$\mathrm{t}$} & \multirow[b]{2}{*}{ Sig. } \\
\hline & & $\mathrm{B}$ & Std. Error & & & \\
\hline \multirow[t]{4}{*}{1} & (Constant) & ,477 & ,745 & & 6,640 &, 525 \\
\hline & Temporary & $-12,638$ & 2,019 &,- 621 & $-6,260$ & ,000 \\
\hline & Permanent & 11,759 & 4,679 & ,249 & 2,513 & ,015 \\
\hline & Size &,- 016 &, 026 &,- 059 &,- 604 & ,548 \\
\hline
\end{tabular}

a. Dependent Variable: Pertumbuhan Laba

Sumber : Hasil pengolahan data menggunakan SPSS 22, 2017 


\section{Uji F}

Tabel 4.7

Uji F

ANOVA $^{a}$

\begin{tabular}{|ll|r|r|r|r|r|}
\hline Model & & Sum of Squares & Df & Mean Square & F & Sig. \\
\hline 1 & Regression & 5,085 & 3 & 1,695 & 17,601 &, $000^{\circ}$ \\
& Residual & 5,008 & 52 &, 096 & & \\
& Total & 10,092 & 55 & & & \\
\hline
\end{tabular}

a. Dependent Variable: Pertumbuhan Laba

b. Predictors: (Constant), Size, Permanent, Temporary

Sumber : Hasil pengolahan data menggunakan SPSS 22, 2017

\subsubsection{Uji Moderate Regresion Analysis (MRA)}

Dan jika persamaan Xi dan XiZi tidak signifikan maka Z bukanlah variabel moderator tetapi sebagai variabel predictor (independen) (Ghozali, 2016:219). Ketiga persamaan tersebut adalah :

$\mathrm{Yi}=\mathrm{a}+\mathrm{b} 1 \mathrm{x} 1+\mathrm{e}$

$\mathrm{Yi}=\mathrm{a}+\mathrm{b} 1 \mathrm{x} 1+\mathrm{b} 2 \mathrm{Zi}+\mathrm{e}$

$\mathrm{Yi}=\mathrm{a}+\mathrm{b} 1 \mathrm{x} 1+\mathrm{b} 2 \mathrm{zi}+\mathrm{b} 3 \mathrm{x} 1 * \mathrm{Zi}+\mathrm{e}$

Persamaan moderator 1

$\mathrm{Yi}=\mathrm{a}+\mathrm{b} 1 \times 2+\mathrm{e}$

$\mathrm{Yi}=\mathrm{a}+\mathrm{b} 1 \times 2+\mathrm{b} 2 \mathrm{Zi}+\mathrm{e}$

$\mathrm{Yi}=\mathrm{a}+\mathrm{b} 1 \mathrm{x} 2+\mathrm{b} 2 \mathrm{zi}+\mathrm{b} 3 \times 2 * \mathrm{Zi}+\mathrm{e}$

Persamaan moderator 2

Tabel 4.8

Hasil Uji Analisis Regresi Moderasi 1

Model Summary

\begin{tabular}{|l|r|r|r|r|r|}
\hline Model & $\mathrm{R}$ & $\mathrm{R}$ Square & $\begin{array}{c}\text { Adjusted R } \\
\text { Square }\end{array}$ & $\begin{array}{c}\text { Std. Error of the } \\
\text { Estimate }\end{array}$ & Durbin-Watson \\
\hline 1 &, $664^{\mathrm{a}}$ &, 441 &, 431 &, 32316 & 2,127 \\
\hline
\end{tabular}

a. Predictors: (Constant), Temporary

b. Dependent Variable: Pertumbuhan Laba

\begin{tabular}{|l|r|r|r|r|r|}
\hline \multicolumn{7}{|c|}{ Model Summary } \\
\hline 1 & $\mathrm{R}$ & $\mathrm{R}$ Square & $\begin{array}{c}\text { Adjusted R } \\
\text { Square }\end{array}$ & $\begin{array}{c}\text { Std. Error of the } \\
\text { Estimate }\end{array}$ & Durbin-Watson \\
\hline &, $666^{\mathrm{a}}$ &, 444 &, 423 &, 32551 & 2,152 \\
\hline
\end{tabular}

a. Predictors: (Constant), Size, Temporary

b. Dependent Variable: Pertumbuhan Laba

\begin{tabular}{|l|r|r|r|r|r|}
\hline \multicolumn{7}{|c|}{ Model Summary $^{\mathrm{b}}$} \\
\hline 1 & $\mathrm{R}$ & $\mathrm{R}$ Square & $\begin{array}{c}\text { Adjusted R } \\
\text { Square }\end{array}$ & $\begin{array}{c}\text { Std. Error of the } \\
\text { Estimate }\end{array}$ & Durbin-Watson \\
\hline &, $703^{\mathrm{a}}$ &, 495 &, 465 &, 31320 & 2,223 \\
\hline
\end{tabular}

a. Predictors: (Constant), moderator1, Size, Temporary

b. Dependent Variable: Pertumbuhan Laba

Hasil ringkasan output regresi 1 sebagai berikut :

1. Pertumbuhan Laba $=0,003-13,510$ TD R 2 Adj $=0,431$

Nilait $(-0,69)(-6,530)$

2. Pertumbuhan Laba $=0,369-13,422 \mathrm{TD}-0,013 \mathrm{UP} \quad \mathrm{R} 2 \mathrm{Adj}=0,423$

Nilait $(0,473) \quad(-6,45) \quad(-0,470)$

3. Pertumbuhan Laba $=-0,128+-0,128 \mathrm{TD}+0,005+4,344 \mathrm{TD} * \mathrm{UP} \quad \mathrm{R} 2 \mathrm{Adj}=0,465$

Nilait $(-0,164)(-2,554) \quad(0,171) \quad(2,291)$ 
Tabel 4.9

Hasil Uji Analisis Regresi Moderasi 2

\begin{tabular}{|c|c|c|c|c|c|}
\hline \multicolumn{6}{|c|}{ Model Summary } \\
\hline Model & $\mathrm{R}$ & R Square & $\begin{array}{l}\text { Adjusted R } \\
\text { Square }\end{array}$ & $\begin{array}{l}\text { Std. Error of the } \\
\text { Estimate }\end{array}$ & Durbin-Watson \\
\hline 1 &, $341^{\mathrm{a}}$ & ,116 & ,100 &, 40646 & 2,414 \\
\hline \multicolumn{6}{|c|}{$\begin{array}{l}\text { a. Predictors: (Constant), Permanent } \\
\text { b. Dependent Variable: Pertumbuhan Laba }\end{array}$} \\
\hline Model & $\mathrm{R}$ & R Square & $\begin{array}{l}\text { Adjusted R } \\
\text { Square }\end{array}$ & $\begin{array}{l}\text { Std. Error of the } \\
\text { Estimate }\end{array}$ & Durbin-Watson \\
\hline 1 &, $360^{a}$ &, 130 & ,097 & ,40704 & 2,446 \\
\hline
\end{tabular}

a. Predictors: (Constant), Size, Permanent

\begin{tabular}{|l|r|r|r|r|r|}
\hline Model & $\mathrm{R}$ & $\mathrm{R}$ Square & $\begin{array}{c}\text { Adjusted R } \\
\text { Square }\end{array}$ & $\begin{array}{c}\text { Std. Error of the } \\
\text { Estimate }\end{array}$ & Durbin-Watson \\
\hline 1 &, $462^{\mathrm{a}}$ &, 213 &, 168 &, 39072 & 2,480 \\
\hline
\end{tabular}

a. Predictors: (Constant), moderator2, Size, Permanent

b. Dependent Variable: Pertumbuhan Laba

Hasil ringkasan output regresi 2 sebagai berikut:

1. Pertumbuhan $\mathrm{Laba}=0,063+16,113 \mathrm{PD}$ Nilait $(1,127)(2,662)$

2. Pertumbuhan Laba $=0,955+16,283 \mathrm{PD}-0,031 \mathrm{UP} \quad \mathrm{R} 2 \mathrm{Adj}=0,97$

Nilait $(0,983)(2,685) \quad(-0,920)$

3. Pertumbuhan Laba $=1,995+238,330$ PD $-0,063$ UP -7,954PD*UP R2 Adj $=0,168$

Nilait $(1,933)(2,517) \quad(-1,877) \quad(-2,349)$

\subsection{Pembahasan Penelitian}

Dari hasil penelitian yang sudah dipaparkan diatas, maka dapat di interpretasikan sebagai berikut:

1. Hasil uji statistik $t$, menunjukan bahwa temporary difference memiliki nilai signifikan sebesar 0,00 dimana nilai $0,00<0,05$, maka hipotesis diterima yang artinya temporary difference berpengaruh terhadap pertumbuhan laba. Hasil tersebut sesuai dengan penelitian Anik Fadilah (2013) yang menyatakan bahwa temporary difference berpengaruh terhadap pertumbuhan laba.Temuan ini tidak sejalan dengan Lestari (2011) yang mengatakan bahwa perbedaan temporer tidak berpengaruh secara signifikan terhadap pertumbuhan laba. Maka alasan pertama yang menyatakan temporary difference berpengarh terhadap pertumbuhan laba dapat dijelaskan oleh analisis deskriptif dan didukung dengan hasil uji hipotesis pada nilai koefisienya.

2. Hasil uji statistic $t$, menunjukan bahwa perubahan permanent difference memiliki nilai signifikan sebesar 0,015 dimana nilai $0,015<0,05$ sehingga hipotesis diterima yang artinya permanent difference berpengaruh terhadap pertumbuhan laba. Hasil ini sesuai dengan penelitian Fadhila (2017) menemukan bahwa permanent difference book tax differences berpengaruh terhadap pertumbuhan laba. Hasil ini tidak sejalan dengan penelitian Lestari (2011), Brolin (2014) yang menyatakan permanent difference tidak berpengaruh terhadap pertumbuhan laba.

3. Ukuran perusahaan dapat memoderasi hubungan antara temporary difference terhadap pertumbuhan laba, karena nilai signifikan X1<moderator 1 atau-2,554<2,291 sehingga hipotesis diterima. Berarti ukuran perusahaan dapat memoderasi hubungan antara temporary difference terhadap pertumbuhan laba, maka dapat disimpulkan bahwa variabel $\mathrm{Z}$ adalah variabel pemoderasi.

4. Ukuran Perusahaan dapat memoderasi hubungan antara permanent difference terhadap pertumbuhan laba, karena nilai signifikan X2 $<$ moderator2 atau $0,015<0,023$ sehingga hipotesis diterima. Berarti ukuran perusahaan dapat memoderasi hubungan antara permanent difference 
terhadap pertumbuhan laba, Berarti ukuran perusahaan dapat memoderasi hubungan antara permanent differenceterhadap pertumbuhan laba, maka dapat disimpulkan bahwa variabel $\mathrm{Z}$ adalah variabel pemoderasi.

\section{Simpulan Dan Saran}

\subsection{Simpulan}

Berdasarkan hasil penelitian yang telah dilakukan pada bab-bab sebelumnya, maka diperoleh simpulan : 1) Temporary difference dari book tax differences berpengaruh terhadap pertumbuhan laba.2) Pemanent difference dari book tax differences berpengaruh terhadap pertumbuhan laba. 3) Temporary difference dengan ukuran perusahaan sebagai variabel pemoderasi secara signifikan berpengaruh terhadap pertumbuhan laba. Maka dapat simpulkan bahwa variabel ukuran perusahaan dapat memperkuat variabel bebas terhadap variabel terikat, 4) Permanent difference dengan ukuran perusahaan sebagai variabel pemoderasi secara signifikan berpengaruh terhadap pertumbuhan laba. Maka dapat simpulkan bahwa variabel ukuran perusahaan dapat memperkuat variabel bebas terhadap variabel terikat.

\subsection{Saran}

Beberapa saran yang dapat digunakan adalah: 1) Selanjutnya dapat menggunakan periode yang berbeda untuk menghasilkan penelitian yang lebih baik dan periode penelitian harus dilakukan secara berkala agar perusahaan dapat mempertahankan laba yang diperoleh saat ini sampai masa yang akan datang karena kondisi ekonomi berubah-uba setiap periode. 2) Sebaiknya menambahkan sampel dalam penelitian ini, dan 3) Perlu mengembangkan dan melakukan kombinasi variabel dari faktor pajak dan non pajak untuk melihat pertumbuhan laba, seperti : manajemen laba, penghindaran pajak, dan perbedaan peraturan pelaporan, atau menambahkan ROA (Return Of Assets) sebagai variabel kontrol.

\section{Daftar Pustaka}

Arikunto, Suharsimi. 2002. Metodologi Penelitian. Penerbit PT. Rineka Cipta. Jakarta. Bambang, Prasetyo, dan Jannah, Lina Miftahul. 2008. Metode Penelitian Kuantitatif: Teori dan Aplikasi, PT Raja Grafindo Persada. Jakarta.

Broklin, Amos Rico. 2014. Analisis Pengaruh Book Tax Differences Terhadap Pertumbuhan Laba Pada Perusahaan Manufaktur Yang Terdaftar Di Bursa Efek Indonesia. Skripsi Universitas Diponegoro. Semarang.

Hutabarat, Loesiana Maulina. 2013. Pengaruh Tax Differences Terhadap Pertumbuhan Laba. Pada Perusahaan Food And Beverages Yang Terdaftar Di Bursa Efek Di Indonesia. Jurnal Akuntansi Universitas Gorontalo.

Harahap, Sofyan Syafri. 2011. Analisis Kritis Atas Laporan Keuangan. Raja grafindo Persada. Jakarta.

Ghozali, Imam. 2016.Aplikasi Analisis Multivariete SPSS 23 Edisi 8. Badan Penerbit Universitas Diponrgoro. Semarang.

Ghozali, Imam dan Chariri, Anis. 2003. Teori Akuntansi. Badan Penerbit Universitas Diponegoro. Semarang.

Lestari, Budi. 2011. Analisis Pengaruh Book-Tax Differences Terhadap Pertumbuhan Laba Pada Perusahaan Manufaktur Yang Terdaftar Di Bursa Efek Di Indonesia. Skipsi Universitas Diponegoro. Semarang.

Mahya, Lummatul. 2016. Tingkat Hutang, Likuiditas, Ukuran Perusahaan Terhadap Persistensi Laba Dengan Book Tax Differences Sebagai Variabel Moderating. Pada Perusahaan Yang Terdaftar di Indeks LQ45 Bursa Efek Indonesia. Skripsi Universitas Islam Negeri Maulana Malik Ibrahim. Malang. 
Pramitasari, Bety. 2009. Analisis Book Tax Differences Terhadap Persistensi Laba Dan Laba Akrual Sebagai Variabel Moderating. Pada Perusahaan Bursa Efek Yang Terdaftar Di Bursa Efek Indonesia. Jurnal Akuntansi dan Investasi. Vol. 10 No. 1, halaman: 35-45. Januari

Putro, Dionusius Purwandono Suryo. 2016. Analisis Pengaruh Komponen Klasifikasi Book-Tax Differences Terhadap Persistensi Laba Pada Perusahaan Manufaktur Yang Terdaftar Di Bursa Efek Indonesia. Skripsi Universitas Diponegoro. Semarang.

Rosanti, Nur Aini. 2013. Pengaruh Book-Tax Differences Terhadap Pertumbuhan Laba Pada Perusahaan Manufaktur Yang Terdaftar Di Bursa Efek Di Indonesia. Skripsi Universitas Diponegoro. Semarang.

Saputro, Nugroho Adi. 2011. Pengaruh Book-Tax Differences Terhadap Pertumbuhan Laba Pada Perusahaan Manufaktur Yang Terdaftar Di Bursa Efek Di Indonesia. Skripsi Universitas Diponegoro. Semarang.

Sudarmadji, Ardi Murdoko dan Sularto, Lana. 2007. Pengaruh Ukuran Perusahaan, Profitabilitas, leverage, dan Tipe Kepemilikan Perusahaan Terhadap Luas Voluntary Disclosure Laporan Keuangan Tahunan. Proceeding PESAT. Vol 2.

Zain, M. 2008. Manajemen Perpajakan. Salemba Empat. Jakarta. 